\title{
Assessment of the effects of cigarette smoking on lung functions and glucose metabolism in asymptomatic current cigarettes smokers
}

\author{
Rania A. Abdelraoof ${ }^{1}$, Samiha M. Aboubakr ${ }^{1}$, Heba H. Eltrawy ${ }^{1}$, Inass H. Ahmad ${ }^{2}$ \\ ${ }^{1}$ Chest Diseases Department, Faculty of Medicine for Girls, Cairo, Al-Azhar University, Egypt. \\ ${ }^{2}$ Endocrinology Department, Faculty of Medicine for Girls, Cairo, Al-Azhar University, Egypt.
}

\section{ABSTRACT}

Background: tobacco smoking has been considered a risk factor for obstructive airway diseases, insulin resistance and development of type 2 diabetes mellitus (DM).

Aim: to assess the effects of cigarette smoking on lung functions and glucose metabolism in asymptomatic current cigarettes smokers.

Methodology: this case-control study was conducted on 100 asymptomatic current cigarette smokers and 100 age and sex matched lifelong non-smokers. Data regarding age, sex, smoking history including age of starting, smoking index and smoking duration were recorded. Spirometric-indices (VC \%, FVC\%,, FEV1 \%,FEV $/$ FVC ratio, FEF25-75\%), serum fasting plasma glucose $\mathrm{mg} / \mathrm{dl}$ (FPG) and glycated hemoglobin $\%\left(\mathrm{HbA}_{1} \mathrm{C} \%\right)$ were measured.

Results: obstructive ventilatory defect and small airways obstruction were significantly higher in asymptomatic smokers than non-smokers ( $21 \%$ vs. $7 \%$ and $42 \%$ vs. $10 \%$ respectively) (p 0.004 and 0.001 respectively). Among smokers the frequencies of the pre-DM and DM detected by FPG there were higher than non-smokers $(41 \%$ vs. $9 \%$ and $10 \%$ vs. $1 \%$ respectively). Moreover, there was higher frequencies of pre-DM and DM detected by $\mathrm{HbA}_{1} \mathrm{C}$ among smokers compared to non-smokers (60\% vs. $11 \%$ and $10 \%$ vs. $1 \%$ respectively) (p 0.001). In smokers group both $\mathrm{FEV}_{1} / \mathrm{FVC}$ and $\mathrm{FEF} 25-75 \%$ was positively correlated with age of starting smoking /yrs (p 0.001), and negatively correlated with smoking index, smoking duration, FPG and $\mathrm{HbA}_{1} \mathrm{C}(\mathrm{p} 0.001)$. The $\mathrm{HbA}_{1} \mathrm{C}$ was positively correlated with smoking index and smoking duration and negatively correlated with age of starting smoking/yrs $(p<0.05)$. Smokers have 17.1 more risk of developing DM, 3.5 more risk of developing obstructive ventilatory defects and 6.5 more risk of developing small airways obstruction compared to non-smokers.

Conclusion: smoking is a risk factor for development of DM, obstructive ventilatory defect and small airways obstruction. Both reduced ventilatory functions and increased FPG and $\mathrm{HbA}_{1} \mathrm{C}$ negatively affected each other's.

JRAM 2021; 2 (1): 37-45

Keywords: Smoking, pulmonary function tests, glycosylated hemoglobin, diabetes, small airway obstruction

Submission Date: 24 June 2020

Acceptance Date 2 July 2020

Corresponding author: Rania A. Abdelraoof, chest diseases department, faculty of medicine for girls, Caro, Al-Azhar university Egypt. Tel: 01060289024. E-mail: ramye176@gmail.com

Please cite this article as: Abdelraoof RA, Aboubakr SM, Eltrawy HH, Ahmad IH. Assessment of the effects of cigarette smoking on lung functions and glucose metabolism in asymptomatic current cigarettes smokers. JRAM 2021; 2 (1):37-45. DOI:

$10.21608 /$ jram.2020.33764.1066

\section{INTRODUCTION}

Smoking as a method of consumption is most frequently used for tobacco, chiefly in the form of burnt tobacco and predominately cigarettes ${ }^{[1]}$. The WHO stated that tobacco smoking killed 100 million persons world-wide in the $20^{\text {th }}$ century and assumed that it could kill one billion persons around the world in the twenty-one century [2]. Individual research's revealed prevalence rate of tobacco smoking in Egypt that fluctuated between $19.7 \%$ in the Global Adult
Tobacco Survey report to $30 \%$ in Egyptian populationbased studies ${ }^{[3]}$.

Smoking induced inflammatory process that leads to long-lasting changes in the lungs. The airways walls become thicker and mucus production is increased. Damage to the bronchial walls causes emphysema, and the lungs lose their elastic proprieties. Stimulation of irritant receptors in the bronchi constricts bronchial smooth muscles through a cholinergic pass-way via the 
vagus nerve ${ }^{[4]}$. Additionally, accumulation of inflammatory cells e.g. B-cells, CD8+ T-lymphocytes, macrophages and neutrophils in the bronchi with secretion of its mediators, in response to irritants substances found in inhaled smoke produced an inflammatory phase. These continuing inflammation leads to structural and functional alterations in the lungs, which hasten the development of bronchial obstruction with subsequent development of chronic obstructive pulmonary disease (COPD) ${ }^{[5]}$.

The link between cigarette smoking and the increased $\mathrm{HbA}_{1} \mathrm{C}$ may be due to nicotine, which has been demonstrated to increase plasma levels of catecholamines, which increase hepatic glycolysis and gluconeogenesis. The catecholamines might reduce the number of insulin binding sites as well as decrease the synthesis of glucose transporters. Smoking may directly decrease insulin sensitivity which is one of the crucial factors of glucose tolerance ${ }^{[6]}$. Additionally, constituents existing in tobacco smoke certainly generate free radical processes, interfere with vascular homeostasis and appropriate functioning of the vascular endothelium, and also increase inflammation/ oxidative stress, in addition to directly destructing $\beta$ cell function ${ }^{[7]}$. This study was conducted to assess the effects of cigarette smoking on lung functions and glucose metabolism in asymptomatic current cigarettes smokers.

\section{SUBJECTS AND METHODS}

\section{Type, place, and period of the study}

This case-control study was performed at chest diseases department faculty of medicine for girls, AlAzhar University, during the period from January 2020-June 2020.

\section{Study population}

The study was conducted on 200 healthy adults classified into two groups:

- Smokers group: Included 100 asymptomatic current smokers (serve as case group).

- Non-smokers group: Included 100 life-long non-smokers subjects with age, sex and BMI matched with cases (serve as a control group).

\section{Exclusion criteria}

Individuals with known chest diseases or DM were excluded from the study. Additionally, anemic patients and patients with chronic diseases (liver or kidney or gum disease, H. pylori infection) were also excluded from the study as they cause elevation of $\mathrm{HbA}_{1} \mathrm{C}$.

\section{Ethical consideration}

The study protocol was approved by ethical review committee of Faculty of Medicine for Girls, Cairo, AlAzhar University, Egypt. Participation was voluntary; an informed written consent was taken from each participant before enrolment into the study. Data were unnamed and coded to guarantee privacy of the participants.

\section{Methods}

Thorough history was taken with special emphasis on age/yrs, sex, age of starting smoking/yrs., number of cigarettes smoked daily and duration of smoking/yrs. The smoking index (pack/year) was calculated as a number of packs smoked daily multiplied by number of years of smoking. The body mass index (BMI) was calculated according to the following equation [weight $(\mathrm{kg}) /$ height $\left.(\mathrm{m})^{2}\right]$. Liver and renal function tests as well as complete blood count were done to exclude participates with chronic diseases that affect $\mathrm{HbA}_{1} \mathrm{C}$ level.

Spirometry was carried out using SPIROSIFT SP5000, (Japan). The following measurements were recorded; vital capacity (VC \%), forced vital capacity (FVC \%), forced expiratory volume in the first second $\left(\mathrm{FEV}_{1} \%\right), \mathrm{FEV}_{1} \backslash \mathrm{FVC}$ ratio, forced expiratory flow rate 25-75 (FEF25-75\%). Spirometric-indices were calculated using the best out of three technically acceptable performances in accordance with the recommendations of the ERS ${ }^{[8]}$. To assess the frequencies of obstructive ventilatory defects, the study participants were classified based on $\mathrm{FEV}_{1} \backslash \mathrm{FVC}$ and $\mathrm{FEV}_{1} \%$ predicted ratio into: 1) obstructive ventilatory defect $\left(\mathrm{FEV}_{1} / \mathrm{FVC}<70 \%\right.$ and $\left.\mathrm{FEV}_{1}<80 \%\right)$, 2) No obstructive ventilatory defect $\left(\mathrm{FEV}_{1} / \mathrm{FVC} \geq 70 \%\right.$ and $\mathrm{FEV}_{1} \geq 80 \%$ ). They also classified based on FEF 25$75 \%$ into: 1) Small airways obstruction $(<65)$, and 2) No small airways obstructions $(\geq 65)^{[9]}$.

Venous blood sample was taken after an 8 hour overnight fasting for $\mathrm{HbA} 1 \mathrm{C} \%$ and fasting plasma glucose mg/dl (FPG) measurement. Studied Participants were categorized into three groups based on either FPG mg/dl [No DM $(<100 \mathrm{mg} / \mathrm{dl})$, pre-DM $(100-125 \mathrm{mg} / \mathrm{dl})$ and $\mathrm{DM}(\geq 126 \mathrm{mg} / \mathrm{dl})]$ and/or $\mathrm{HbA}_{1} \mathrm{C}[$ no DM $(<5.7 \%)$, pre-DM (5.7-6.4\%), AND $\mathrm{DM}(\geq 6.5 \%)]^{[10]}$.

\section{Statistical analysis}

The studied data were analyzed by Statistical Program for Social Science (SPSS) version 24. Parametric variables were presented as mean \pm standard deviation (SD). Non-parametric variables were presented as numbers and percentages. The Independent-samples ttest was used to compare between two means (for normally distributed data). Chi-square test was used to compare non-parametric data. Pearson's correlation coefficient (r) was used to assess the relationship between the two parametric variables in the same group. The Odds ratio (OR), ratio of odds of event occurring in exposed vs. unexposed group. OR are used to estimate how strongly a variable is associated with the outcome of interest. Probability was determined as: P-value $<0.05$ was considered significant, $\mathrm{P}$-value $<0.001$ was considered highly significant, and P-value > 0.05 was considered insignificant ( $95 \%$ confidence interval). 


\section{RESULTS}

Table (1) shows no statistically significant difference between smokers' group and non-smokers group regarding age, sex, and $\mathrm{BM}(\mathrm{p}>0.05)$. The $\mathrm{FEV}_{1} / \mathrm{FVC}$ ratio was statistically significantly decreased in smokers compared to non-smokers (p 0.001). Moreover, FPG $\mathrm{mg} / \mathrm{dl}$ and $\mathrm{HbA}_{1} \mathrm{C}$ were highly statistically significantly increased in smokers' group than non-smokers group (p 0.001). Table (2) shows that the obstructive ventilatory defect and small airways obstruction were more frequent among smokers than non-smokers ( $p \quad 0.004$ and 0.001 respectively). The frequencies of pre-DM and DM detected by either FPG or $\mathrm{HbA}_{1} \mathrm{C}$ were more common among smokers than non-smokers (p 0.001 each). Moreover, there was concordance of DM frequency detected by either FPG or $\mathrm{HbA}_{1} \mathrm{C}$ methods among both groups, with discordance of the frequency of pre DM detected by either FPG or $\mathrm{HbA}_{1} \mathrm{C}(41 \%$ vs. $60 \%$ in smokers and $9 \%$ vs. $11 \%$ in non-smokers respectively). Table (3) and figures (1-4) show that among smokers group the $\mathrm{FEV}_{1} / \mathrm{FVC}$ ratio was positively correlated with age of starting smoking/yrs, $\mathrm{FEV}_{1} \%$, FVC \%, VC $\%$, and FEF25-75\% (p 0.001 each), while it was negatively correlated with smoking index, smoking duration/yrs and FPG mg/dl (p 0.001). Among smokers the FEF25-75\% was positively with age of starting smoking/yrs, Pre-BD $\mathrm{FEV}_{1} / \mathrm{FVC}$ ratio, $\mathrm{FEV}_{1} \%$, FVC $\%$, VC\%, and Post-BD FEV $1 /$ FVC ratio $(\mathrm{p}<0.05)$, while it was negatively correlated with age/yrs, smoking index, smoking duration/yrs, FPG mg/dl and $\mathrm{HbA}_{1} \mathrm{C}(\mathrm{p}<0.05)$. The $\mathrm{HbA}_{1} \mathrm{C}$ was positively correlated with age/yrs, smoking index, smoking duration/yrs. and FPG mg/dl, while it was negatively correlated with age of starting smoking/yrs, pre-BD $\mathrm{FEV}_{1} / \mathrm{FVC}$ ratio, $\mathrm{FEV} 1 \%$, FVC\%, VC\%, FEF25-75\%, and post-BD $\mathrm{FEV}_{1} / \mathrm{FVC}$ ratio $(\mathrm{p}<0.05)$. Table (4) shows that smokers have 17.1 more risk for developing DM (p 0.001), and 3.5 more risk for developing obstructive ventilatory defect (p 0.006) and 6.5 more risk for developing small airways obstruction compared to age, sex and BMI matched non-smokers (p 0.001$)$.

Table (1): Comparison of all studied variables between smokers' group and non-smokers group

\begin{tabular}{|c|c|c|c|c|c|}
\hline \multicolumn{2}{|c|}{ Demographic data } & $\begin{array}{l}\text { Smokers } \\
(\mathrm{N}=100)\end{array}$ & $\begin{array}{c}\text { Non-smokers } \\
(\mathrm{N}=100)\end{array}$ & Test & $\mathbf{P}$ \\
\hline Age/yrs & Mean \pm SD & $41.59 \pm 13.52$ & $39.99 \pm 8.91$ & $1.48^{\#}$ & 0.14 \\
\hline Sex & $\begin{array}{l}\text { Male } \\
\text { Female }\end{array}$ & $\begin{array}{l}87(87 \%) \\
13(13 \%)\end{array}$ & $\begin{array}{l}85(85 \%) \\
15(15 \%)\end{array}$ & $1.44^{\mathrm{a}}$ & 0.15 \\
\hline BMI $\left(\mathrm{kg} / \mathrm{m}^{2}\right)$ & Mean \pm SD & $26.66 \pm 3.16$ & $27.40 \pm 4.52$ & $0.36^{\#}$ & 0.71 \\
\hline Age of starting smoking/yrs & Mean \pm SD & $24.44 \pm 8.88$ & ---- & ---- & ---- \\
\hline Smoking duration /yrs & Mean \pm SD & $29.18 \pm 10.94$ & ---- & ---- & ---- \\
\hline Smoking index (pack/year) & Mean \pm SD & $22.82 \pm 9.37$ & ---- & ---- & ---- \\
\hline FEV $_{1} / \mathrm{FVC}$ ratio & Mean \pm SD & $81.54 \pm 9.72$ & $87.70 \pm 9.73$ & $9.30^{\#}$ & $0.001 *$ \\
\hline $\mathrm{FEV}_{1} \%$ & Mean \pm SD & $80.67 \pm 8.71$ & $79.61 \pm 5.52$ & $0.31^{\#}$ & 0.75 \\
\hline FVC\% & Mean \pm SD & $74.63 \pm 5.79$ & $76.35 \pm 5.52$ & $0.89^{\#}$ & 0.38 \\
\hline $\mathrm{VC} \%$ & Mean \pm SD & $79.28 \pm 5.82$ & $81.06 \pm 7.13$ & $1.6^{\#}$ & 0.112 \\
\hline FEF25-75 \% & Mean \pm SD & $64.55 \pm 7.75$ & $65.91 \pm 3.05$ & $1.2^{\#}$ & 0.31 \\
\hline FPG mg/dl & Mean \pm SD & $107.26 \pm 16.29$ & $86.99 \pm 9.69$ & $7.51^{\#}$ & $0.001 *$ \\
\hline $\mathrm{HbA}_{1} \mathrm{C} \%$ & Mean \pm SD & $5.89 \pm 0.72$ & $4.93 \pm 0.54$ & 7.91 \# & $0.001 *$ \\
\hline
\end{tabular}

Table (2): Comparison of frequencies of obstructive ventilatory defect, small airway obstruction and DM between smokers' group and non-smokers group

\begin{tabular}{|c|c|c|c|c|c|}
\hline Studied variables & & $\begin{array}{l}\text { Smokers } \\
(\mathrm{N}=100)\end{array}$ & $\begin{array}{l}\text { Non-smokers } \\
\quad(\mathrm{N}=100)\end{array}$ & Test & $\mathbf{P}$ \\
\hline $\begin{array}{l}\text { Obstructive ventilatory defect } \\
\qquad\left(\mathrm{FEV}_{1} / \mathrm{FVC}<70 \text { and } \mathrm{FEV}_{1}<80 \%\right)\end{array}$ & $\begin{array}{l}\text { No } \\
\text { Yes }\end{array}$ & $\begin{array}{l}79(79 \%) \\
21(21 \%)\end{array}$ & $\begin{array}{c}93(93 \%) \\
7(7 \%)\end{array}$ & $8.1^{\mathrm{a}}$ & $0.004 *$ \\
\hline $\begin{array}{l}\text { Small airway obstruction } \\
\qquad(\text { FEF25-75\%<65) }\end{array}$ & $\begin{array}{l}\text { No } \\
\text { Yes }\end{array}$ & $\begin{array}{l}58(58 \%) \\
42(42 \%)\end{array}$ & $\begin{array}{l}90(90 \%) \\
10(10 \%)\end{array}$ & $26.6^{\mathrm{a}}$ & $0.001 *$ \\
\hline $\mathrm{DM}\left(\mathrm{HbA}_{1} \mathrm{C}\right)$ & $\begin{array}{l}\text { No DM } \\
\text { Pre DM } \\
\text { DM }\end{array}$ & $\begin{array}{l}30(30 \%) \\
60(60 \%) \\
10(10 \%)\end{array}$ & $\begin{array}{c}88(88 \%) \\
11(11 \%) \\
1(1 \%)\end{array}$ & $69.7^{\mathrm{a}}$ & $0.001 *$ \\
\hline DM (FPG) & $\begin{array}{l}\text { No DM } \\
\text { Pre DM } \\
\text { DM }\end{array}$ & $\begin{array}{l}49(49 \%) \\
41(41 \%) \\
10(10 \%)\end{array}$ & $\begin{array}{c}90(90 \%) \\
9(9 \%) \\
1(1 \%)\end{array}$ & $39.9^{a}$ & $0.001 *$ \\
\hline
\end{tabular}


Table (3): Correlation study of $\mathrm{HbA}_{1} \mathrm{C} \%$, FEF 25-75\%, FEV $/ \mathrm{FVC}$ ratio, with other studied variables in smokers' group

\begin{tabular}{|c|c|c|c|c|c|c|}
\hline \multirow{3}{*}{ Studied variables } & \multicolumn{6}{|c|}{ Smokers group } \\
\hline & \multicolumn{2}{|c|}{$\mathrm{HbA}_{1} \mathrm{C}$} & \multicolumn{2}{|c|}{ FEF $25-75 \%$} & \multicolumn{2}{|c|}{ FEV $1 / F V C$ ratio } \\
\hline & $\mathbf{r}$ & $\mathbf{P}$ & $\mathbf{r}$ & $\mathbf{p}$ & $\mathbf{r}$ & $\mathbf{P}$ \\
\hline Age/yrs & 0.36 & $0.001 *$ & -0.25 & $0.011 *$ & -0.22 & $0.027 *$ \\
\hline BMI $\left(\mathrm{kg} / \mathrm{m}^{2}\right)$ & 0.11 & 0.29 & -0.007 & 0.94 & 0.04 & 0.685 \\
\hline Smoking index (pack/yr.) & 0.56 & $0.001 *$ & -0.97 & $0.001 *$ & -0.96 & $0.002 *$ \\
\hline Smoking duration/yr. & 0.54 & $0.002 *$ & -0.97 & $0.001 *$ & -0.98 & $0.001 *$ \\
\hline Age of starting smoking/yr. & -0.46 & $0.001^{*}$ & 0.95 & $0.001 *$ & 0.95 & $0.002 *$ \\
\hline Pre-BD FEV 1 /FVC ratio & -0.58 & $0.001 *$ & 0.97 & $0.001 *$ & ---- & ---- \\
\hline FEV $1 \%$ & -0.58 & $0.003^{*}$ & 0.97 & $0.001 *$ & 0.98 & 0.001 \\
\hline FVC\% & -0.58 & $0.001 *$ & 0.98 & $0.001 *$ & 0.98 & $0.001 *$ \\
\hline $\mathrm{VC} \%$ & -0.54 & $0.002 *$ & 0.97 & $0.001 *$ & 0.97 & $0.001 *$ \\
\hline FEF $25-75 \%$ & -0.62 & $0.003^{*}$ & ---- & ---- & 0.97 & $0.001 *$ \\
\hline FPG mg/dl & 0.75 & $0.001^{*}$ & -0.88 & $0.003^{*}$ & -0.91 & $0.001 *$ \\
\hline $\mathrm{HbA}_{1} \mathrm{C} \%$ & ---- & ---- & -0.61 & $0.001 *$ & -0.58 & $0.001 *$ \\
\hline
\end{tabular}

(r): Pearson correlation coefficient, *: significant test, BMI: body mass index, FEV1\%: forced expiratory volume in first second, FCV: forced vital capacity, VC: vital capacity, FEF25-75: forced expiratory flow at 25-75 of vital capacity, FEV1/FCV: forced expiratory volume in first second/ forced vital capacity, FPG: fasting plasma glucose, $\mathrm{HbA}_{1} \mathrm{C}$ : Glycated hemoglobin

Table (4): Odd ratio for smoking as risk factors for DM, obstructive ventilatory defect and small airways obstruction

\begin{tabular}{|c|c|c|c|c|c|c|}
\hline \multicolumn{2}{|c|}{ Studied variables } & $\begin{array}{l}\text { Smokers } \\
(n=100)\end{array}$ & $\begin{array}{l}\text { Non-smokers } \\
\quad(\mathbf{n}=\mathbf{1 0 0})\end{array}$ & OR & $95 \% \mathrm{CL}$ & $\mathbf{p}$ \\
\hline $\mathrm{HbA}_{1} \mathrm{C} \%$ & $\begin{array}{l}\text { Normal } \\
\text { Increased }\end{array}$ & $\begin{array}{l}30(30 \%) \\
70(70 \%)\end{array}$ & $\begin{array}{l}88(88 \%) \\
12(12 \%)\end{array}$ & 17.1 & $8.2(35.8)$ & 0.001 \\
\hline $\mathrm{FEV}_{1} / \mathrm{FVC}$ ratio & $\begin{array}{l}\text { Normal } \\
\text { Decreased }\end{array}$ & $\begin{array}{l}79(79 \%) \\
21(21 \%)\end{array}$ & $\begin{array}{c}93(93 \%) \\
7(7 \%)\end{array}$ & 3.5 & $1.4(8.7)$ & 0.006 \\
\hline FEF25-75\% & $\begin{array}{l}\text { Normal } \\
\text { Decreased }\end{array}$ & $\begin{array}{l}58(58 \%) \\
42(42 \%)\end{array}$ & $\begin{array}{l}90(90 \%) \\
10(10 \%)\end{array}$ & 6.5 & $3.03(13.9)$ & 0.001 \\
\hline
\end{tabular}

$\mathrm{FEV}_{1} / \mathrm{FCV}$ : forced expiratory volume in first second/ forced vital capacity, FEF25-75: forced expiratory flow at 25-75 of vital capacity, $\mathrm{Hb} \mathrm{A}_{1} \mathrm{C}$ : Glycated hemoglobin

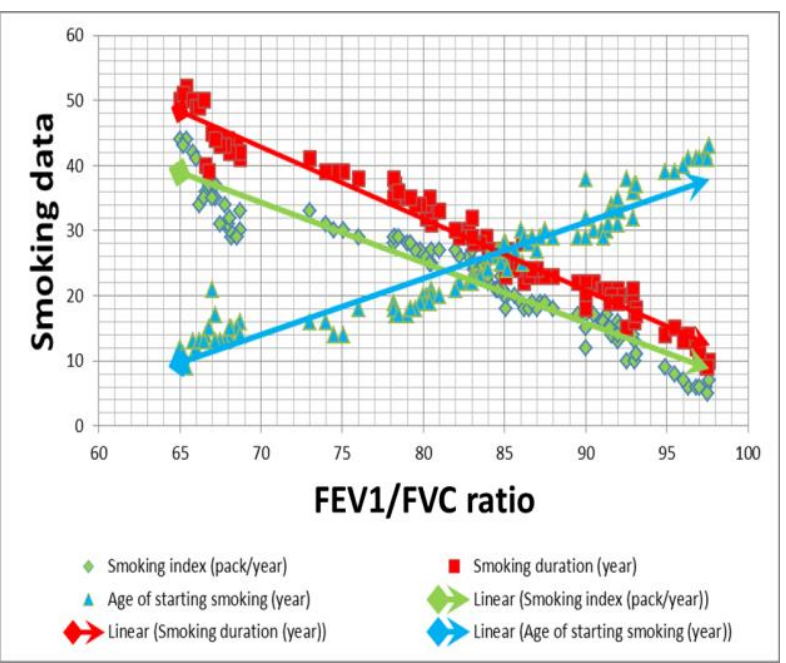

Figure (1): Correlations of $\mathrm{FEV}_{1} / \mathrm{FVC}$ ratio with smoking index, age of starting smoking and smoking duration in smokers' group. It shows that in smokers group the $\mathrm{FEV}_{1} / \mathrm{FVC}$ ratio was positively correlated with age of starting smoking, while it was negatively correlated with smoking index and smoking duration. Pre $\mathrm{BD}$ : pre bronchodilator $\mathrm{FEV}_{1} / \mathrm{FCV}$ : forced expiratory volume in first second/ forced vital capacity

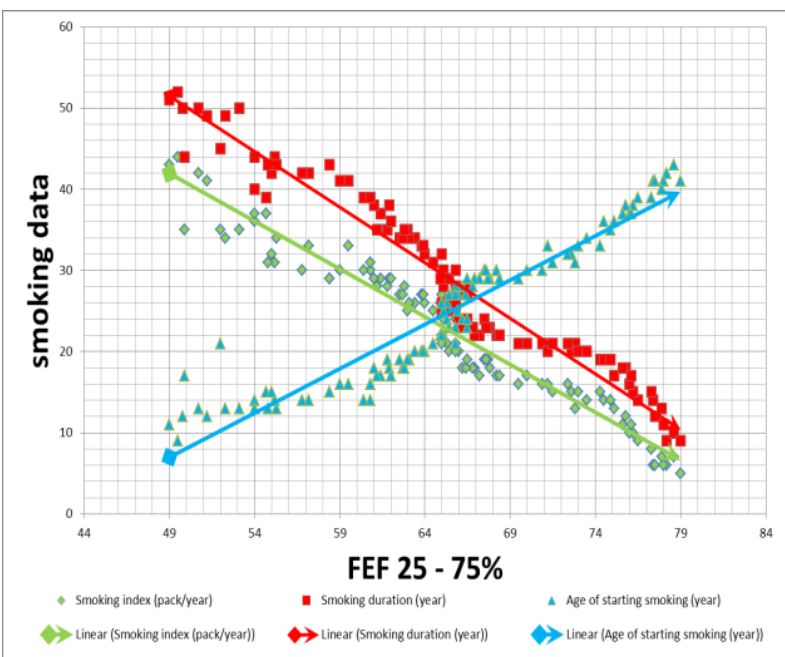

Figure (2): Correlation of FEF25-75\% with smoking index, age of starting smoking and smoking duration in smokers' group. It shows that among smokers the FEF25-75\% was positively correlated with age of starting smoking/yrs, while it was negatively correlated with smoking index and smoking duration/yrs. FEF25-75: forced expiratory flow at 2575 of vital capacity 


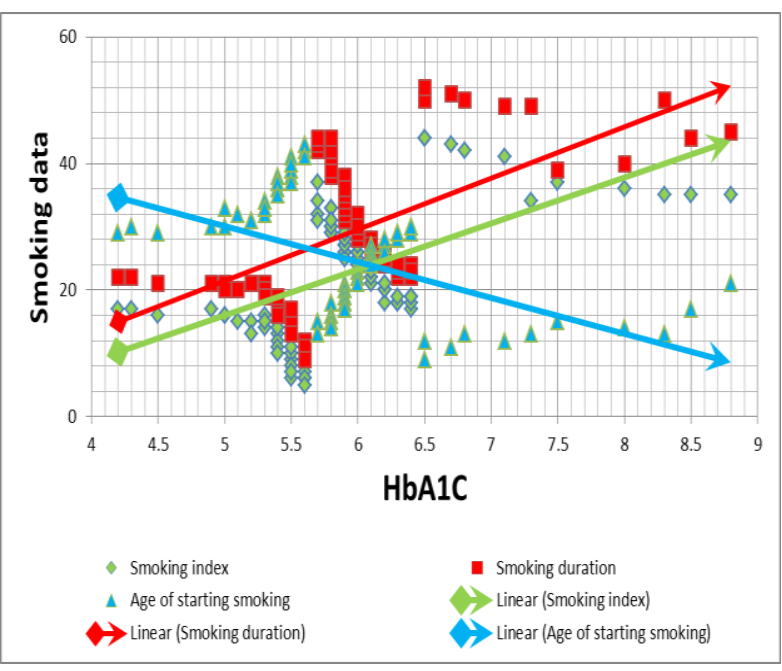

Figure (3): Correlation of $\mathrm{HbA}_{1} \mathrm{C}$ with smoking index, age of starting, and smoking duration smoking in smokers group. It shows that among smokers group the $\mathrm{HbA}_{1} \mathrm{C}$ was positively correlated with smoking index and smoking duration while it was negatively correlated with age of starting smoking/yrs. $\mathrm{HbA}_{1} \mathrm{C}$ : Glycated hemoglobin

\section{DISCUSSION}

Systemic inflammation is a common characteristic of both COPD and $\mathrm{T}_{2} \mathrm{DM}$, which produce insulin resistance, atherosclerosis, and many extra-pulmonary manifestations of COPD ${ }^{[11]}$. Accordingly, this study was conducted to assess the effects of cigarette smoking on lung functions and glucose metabolism in asymptomatic current cigarettes smokers. Hence, age was independent variable for spirometric-indices, and adiposity limit the normal movements of diaphragm and chest ${ }^{[12]}$, we select smokers and non-smokers subjects' matched regarding age, sex and BMI to avoid the synergistic effects of these confounders with smoking on airways function and $\mathrm{HbA}_{1} \mathrm{C}$ level.

In our study the $\mathrm{FEV}_{1} / \mathrm{FVC}$ ratio was the only spirometric-indices that significantly decreased in smokers than non-smokers. This finding points out that a decreased $\mathrm{FEV}_{1} / \mathrm{FVC}$ may be the earliest discriminative index for airway obstruction in asymptomatic smokers. Similarly, Wafy et al. ${ }^{[13]}$ reported that the means of all spirometric-indices were significantly reduced in smokers than non-smokers, although, they are within-normal range. The decreased pulmonary function tests (PFT) in smokers were established to be statistically significant for FEF $25-75 \%$ with no significant difference in other values. Mistry et al. ${ }^{[14]}$ they reported that at every age group, smokers had decreased $\mathrm{FEV}_{1} / \mathrm{FVC}$ ratio making them prone to develop COPD in the future. Nawafleh et al. ${ }^{[15]}$ and. Manikandan et al. ${ }^{[4]}$ reported that the $\mathrm{FEV}_{1} \%, \mathrm{FVC} \%$, $\mathrm{FEV}_{1} / \mathrm{FVC} \%$ and PEFR were reduced in smokers than non-smokers, in all age groups. Additionally, active smoking by healthy adults has been documented to cause declines in PFT evidenced by the quicker decline of $\mathrm{FEV}_{1}{ }^{[16]}$, and reductions in $\mathrm{FEV}_{1} / \mathrm{FVC}$ ratio and FEF25-75\% [17]. Karia et al. ${ }^{[18]}$ reported that the

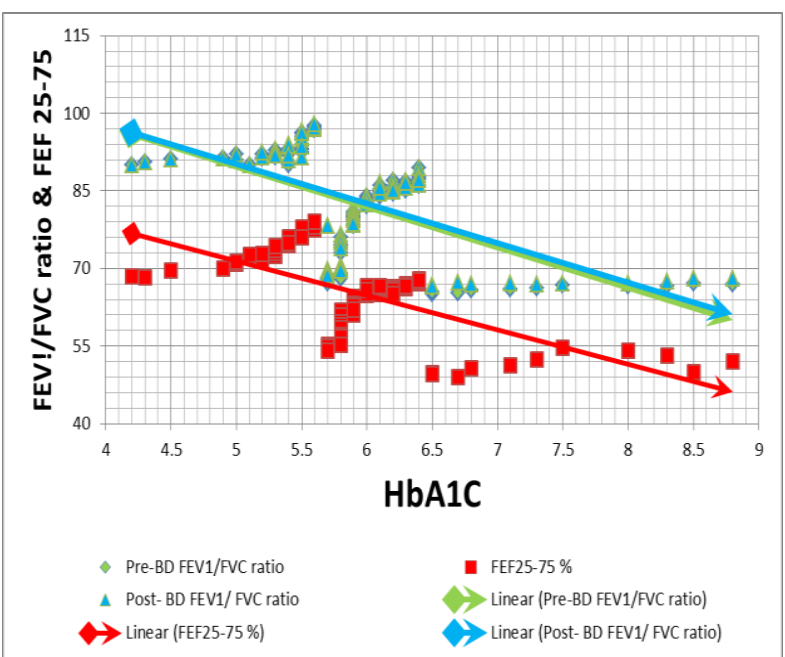

Figure (4): Correlation of $\mathrm{HbA}_{1} \mathrm{C}$ with $\mathrm{FEV}_{1} / \mathrm{FVC}$ ratio and FEF $25-75 \%$ in smokers group. It demonstrates that in smokers group the $\mathrm{HbA}_{1} \mathrm{C}$ was negatively correlated with both $\mathrm{FEV}_{1} / \mathrm{FVC}$ ratio and FEF $25-75 \%$. $\mathrm{FEV}_{1} / \mathrm{FCV}$ : forced expiratory volume in first second/ forced vital capacity, FEF25-75: forced expiratory flow at 25-75 of vital capacity, $\mathrm{HbA}_{1} \mathrm{C}$ : Glycated hemoglobin

spirometric-indices are significantly reduced in smokers than non-smokers. Different results reported by Hasan and Sulaiman ${ }^{[19]}$ as there was no significant difference in $\mathrm{FEV}_{1} / \mathrm{FVC}$ ratio and $\mathrm{FEV}_{1}$ between smokers and nonsmokers. Dugral and Balkanc [20] reported that smokers exhibited better FVC and $\mathrm{FEV}_{1}$ values. However, they exhibited significantly lower $\mathrm{FEV}_{1} / \mathrm{FVC}$ ratios than nonsmokers. The authors concluded that smoking improves lung function in young adults; these are "healthy smokers." This difference may be attributed to that they study students and exclude subjects with evidence of airways obstruction $\left(\mathrm{FEV}_{1} / \mathrm{FVC}<80 \%\right)$.

The current study demonstrated that both obstructive ventilatory defect and small airways obstruction were more frequent among smokers $(21 \%$ and $42 \%$ respectively, $\mathrm{p}=0.004)$ than non-smokers (7\% and $10 \%$ respectively) $(\mathrm{p}=0.001)$. These findings suggest that after adjustment of age, sex and BMI, cigarette smoking have negative impacts on airways function. Nicotine was described to be chemotactic for neutrophils, the main cell to be recruited in smokeinduced pulmonary inflammation and could therefore play a significant role in the initiation of the lung response finally leading to bronchial obstruction. The mixture of direct effects of cigarette smoke and indirect injury caused by inflammatory cells leads to a chain of epithelial alterations leading to airway obstruction [21]. Barthwal ${ }^{[22]}$ documented that airway obstruction was seen in $12.6 \%$ smokers, of which $68.9 \%$ demonstrated mild obstruction and $31 \%$ demonstrated moderate obstruction. Sophie et al. [23] reported that among smokers PFT was abnormal in $72 \%$ of smokers and in $50 \%$ of non-smokers. Abnormal PFT was seen in $69.77 \%$ smokers with pack 
years $<15$ and in $85.6 \%$ of smokers with pack years $>15$, while mixed pattern was the most common abnormality in PFT observed in $35.0 \%$. Manikandan et al. ${ }^{[4]}$ shows that out of 30 cigarette smokers, $13.2 \%$ had obstructive ventilatory defect and $3.3 \%$ had restrictive pattern and $3.3 \%$ had mixed pulmonary impairment. Most of the nonsmokers $(96.0 \%)$ had normal PFT results. Lower incidence of obstructive PFT was documented by Isah et al. ${ }^{[24]}$ who found obstructive ventilatory defect in six smokers $(4 \%)$ and two controls $(4 \%)$. Khalil et al. ${ }^{[25]}$ reported that the $\mathrm{FEV}_{1} / \mathrm{FVC}$ ratio $<70 \%$ was more prevalent among smokers compared with non-smokers $(17.3 \%$ and $6.7 \%$, respectively).

In the early stage of COPD, some indices that reflect large airways functions e.g. $\mathrm{FEV}_{1}$ are generally within normal ranges, although small airways $(<2 \mathrm{~mm})$ functions are impaired [26]. The higher frequency of small airways obstruction than obstructive ventilatory defect among smokers in our study (21\% and $42 \%$ respectively) may be attributed to the well-known fact that small airways are devoid of some protective mechanisms present in the large airways as postulated by Bohadana et al. ${ }^{[21]}$ who documented that the large airways are lined with ciliated cells "mucociliary escalator" that aids in eliminating inspired particles from the lungs. On the other hands, bronchi beyond 14 division do not have this defense, being therefore susceptible to the hazards of inhaled particles, particularly those in the respirable size $(0.5-5 \mu \mathrm{m}) \mathrm{such}$ as particulate substance of the smoke $(0.5 \mu \mathrm{m})$. Additionally, the quantity of deposited particles and the location of deposition may differ based on the physical properties of the smoke particles and the smoking manner (volume and depth of inhalation, etc.). The long-lasting action of cigarette smoke on lung structures make an array of responses that will finally lead to small airways obstruction in the vulnerable smokers. It is reported that $15 \%-20 \%$ of heavy smokers have airways obstruction due to abnormalities in the small airways $(<2 \mathrm{~mm}$ in diameter) [5].

Our study revealed that after adjustment of age, sex and BMI, smokers have 3.5 times increased risk of developing obstructive ventilatory defect ( $p$ 0.006) and 6.5-time increased risk of developing small airways obstruction compared to non-smokers. Similar result was reported by Nighute and Awari ${ }^{[27]}$ as the risk of having reduced PFT was 18 times in smokers than non-smokers. Urrutia et al. ${ }^{[28]}$ stated that the risk of pulmonary disorders was directly linked to the number of cigarettes smoked daily.

In our study $\mathrm{FPG} \mathrm{mg} / \mathrm{dl}$ and $\mathrm{HbA}_{1} \mathrm{C} \%$ were significantly increased in smokers than non-smokers ( $p$ 0.001 ). These results indicate that smoking has longterm negative effects on glucose metabolism. Similar result was reported by Khalil et al. ${ }^{[25]}$ as the FPG and $\mathrm{HbA}_{1} \mathrm{C} \%$ were significantly higher among smokers compared to nonsmokers. Other study reported that there is a significant increase in the $\mathrm{HbA}_{1} \mathrm{C}$ in smokers than non-smokers with no significant difference in FPG between both groups ${ }^{[6]}$. Another study has stated that current smokers show higher $\mathrm{HbA}_{1} \mathrm{C}$ than nonsmokers, even in people without DM ${ }^{[29]}$. Soulimane et al. [30] in their meta-analysis involved individual's from 14 countries recognized that $\mathrm{HbA}_{1} \mathrm{C}$ are elevated in smokers compared to non-smokers without known DM. Dissimilar result was reported by McCulloch et al.[ ${ }^{31]}$ as smokers and non-smokers did not differ significantly regarding $\mathrm{HbA}_{1} \mathrm{C}$ level. Therefore, they suggested that smoking does not have a significant effect on $\mathrm{HbA}_{1} \mathrm{C}$ in patients with $\mathrm{T}_{2} \mathrm{DM}$.

The present study revealed that the frequencies of pre$\mathrm{DM}$ and $\mathrm{DM}$ detected by $\mathrm{HbA}_{1} \mathrm{C}$ were more common in smokers (60 and 10 respectively) than non-smokers (11 and 1 respectively) (p 0.001). These results suggest that after age, sex and BMI adjustment, cigarette smoking is an independent risk factor for DM. This agrees with Foy et al. ${ }^{[32]}$ who studied the association between smoking status (never, former, and current) and occurrence of 5-year $\mathrm{T}_{2} \mathrm{DM}$, in 906 individuals free of DM at baseline. They found that $25 \%$ of current smokers developed DM at five years, compared to $14 \%$ of never smokers. Akter et al. ${ }^{[33]}$ conducted study involved 53,930 Japanese employees, aged 15-83 years, who did not have DM at baseline. They stated that through 3.9 years of median follow-up, $4.5 \%$ persons developed $\mathrm{T}_{2} \mathrm{D}$. This variance in $\mathrm{DM}$ occurrence between the studies may be attributed to different susceptibility of populations under concern.

Our study revealed that after adjustment for age, sex and BMI smokers have 17.1 times increased risk for DM compared to non-smokers. Foy et al. [32] documented that smokers have significantly higher risk for $\mathrm{T}_{2} \mathrm{DM}$ than non-smokers (OR 2.66). Akter et al. ${ }^{[33]}$ reported that the multivariate-adjusted risk ratios for DM were 1, 1.16 and 1.34 for never smokers, former smokers, and current smokers, respectively. Sang-Mo et al. [34] reported that subjects with a history of smoking more likely to have $\mathrm{HA}_{1} \mathrm{C}$ between $5.7-6.4 \%$ compared to those who have $\mathrm{HA}_{1} \mathrm{C}$ below $5.6 \%$ (OR1.091, 1.168 respectively). Cho et al. ${ }^{[29]}$ found that ex-smokers and current smokers had a statistically higher risk for $\mathrm{T}_{2} \mathrm{DM}$, and the risk increased with the number of cigarettes smoked. Additionally, ŚliwińskaMossoń and Milnerowicz ${ }^{[7]}$ stated that smoking is a predictor of the progression of glucose intolerance at both the conversion from normo-glycaemia to impaired glucose tolerance and the increased risk of developing DM.

The negative correlation detected between $\mathrm{HbA}_{1} \mathrm{C}$ and studied spirometric-indices in our study $(\mathrm{p}<0.05)$, indicate that the well-known fact that the underlying inflammatory state that accompany DM have negative effects on airways function with subsequent development of COPD. On the other hand, the underlying systemic inflammatory response in COPD may alter glucose metabolism with subsequent development of DM. Similarly, Jamatia et al. ${ }^{[35]}$ established that FVC 
and $\mathrm{FEV}_{1}$ were roughly negatively correlated with post prandial blood sugar and $\mathrm{HbA}_{1} \mathrm{C}$. Tina et al. ${ }^{[36]}$ found no correlation between both COPD and small airway diseases in spirometry and duration of DM or level of glycemic control. Litonjua et al. ${ }^{[37]}$ in the Normative Aging Study found that the decline of PFT over time was the same in participants with DM and participants without DM. Korean study, found that the reduced PFT is independently linked to the occurrence of $\mathrm{T}_{2} \mathrm{DM}$. FVC and $\mathrm{FEV}_{1}$ were negatively correlated with $\mathrm{T}_{2} \mathrm{DM}$. Therefore, they proposed that the likelihood that the reduced $\mathrm{FEV}_{1}$ and $\mathrm{FVC}$ may precede the development of $\mathrm{T}_{2} \mathrm{DM}{ }^{[38]}$. Dissimilar finding was reported by Baba et al. ${ }^{[39]}$ as they found no association between the prevalence of $\mathrm{FEV}_{1} / \mathrm{FVC}<70 \%$ and DM.

The main strength of the current study is that it is a case-control study thus it confirms the causal relationship between smoking and the outcomes measured (reduced PFT and DM). Additionally, all study participants did not have other risk factors for either reduced PFT or increase $\mathrm{HbA}_{1} \mathrm{C}$ thus the effects of confounders in either airways functions or $\mathrm{HbA}_{1} \mathrm{C}$ are avoided. The limitations of our research are that it was a single center study, so the results cannot be generalized. The smokers differ widely in their smoking manner, making quantitation of the nicotine dose absorbed by an individual smoker and from an individual cigarette are difficult.

\section{CONCLUSIONS}

Results of this study show that, current smokers had a greater incidence of non-manifested airways obstruction than those who are life-long non-smokers with matching of other related factors (age, sex, BMI). Also, results of this study add support to the hypothesis that smoking has long-term effects on glucose homeostasis, an association that cannot be clarified by confounding factors as age, sex, and BMI. Smoking was associated with preclinical or non-manifested reduction of spirometric-indices and higher $\mathrm{HbA}_{1} \mathrm{C}$ levels in a sample of Egyptian current smokers who were non-COPD and non-diabetic adult males. Initiation of smoking cession clinic in every hospital to teach people the importance of not to smoke is recommended. Engaging smoking cessation programs are important strategies for the management of patients with either respiratory diseases or diabetics. Health education campaigns are needed to keep community aware of the risk of smoking and to implement health promotion strategies that help prevent or reduce the incidence of both respiratory diseases and DM among smokers.

\section{Future directions}

- A further larger population-based study is needed to confirm these results.

\section{REFERENCES}

1. Campagna D, Alamo A, Di Pino A, Russo C, Calogero A E, Purrello F et al. Smoking and diabetes: dangerous liaisons and confusing relationships. Diabetology and Metabolic Syndrome 2019; 11(1): 1-12.

2. World Health Organization. "Tobacco could kill one billion by 2100, WHO report warns. "ScienceDaily. Science Daily, 11 February 2008.

3. <www.sciencedaily.com/releases/2008/02/080210 092031.htm>.

4. Fouda S, Kelany M, Moustafa N, Abushouk A I, Hassane A, Sleem A, et al . Tobacco smoking in Egypt: a scoping literature review of its epidemiology and control measures .Eastern Mediterranean Health Journal 2018;24 (2) .

5. Manikandan S, Anandhalakshmi S, and Nageswari AD. Comparison of the effects of various modes of smoking on the pulmonary functions in healthy volunteers. Asian J Pharm Clin Res 2015; 8(3): 289-291.

6. Mehta V, Desai $N$ and Patel $S$. When pulmonary function test is available, should we wait for the COPD symptoms to develop? J Clin Diagn Res 2016; Oct; 10(10): OE08-OE12.

7. Vidhya K. The effects of cigarette smoking on glycosylated hemoglobin $\left(\mathrm{HbA}_{\mathrm{IC}}\right)$ in non-diabetic individuals. International Journal of Advanced Research 2015; 3(12): 566- 571.

8. Śliwińska-Mossoń $\mathbf{M}$ and Milnerowicz H. The impact of smoking on the development of diabetes and its complications. Diabetes and Vascular Disease Research 2017;14 (4): 265-276.

9. Miller MR, Hankinson J, Brusasco V, Burgos F, Casaburi R, Coates AR, et al. Standardization of spirometry. Eur Respir J 2005; 26: 319-338.n

10. GOLD. global initiative for chronic obstructive lung disease 5-26. https://goldcopd.org/wpcontent/uploads/2019/12/GOLD-2020-FINALver1.2-03Dec19_WMV.pdf. Last access 23 October 2019

11. American Diabetes Association. Classification and diagnosis of diabetes, standards of medical care in diabetes. Diabetes Care 2020; 43(supp 1): S14-S31.

12. Rogliani $\mathbf{P}$, Lucà $\mathbf{G}$ and Lauro D. Chronic obstructive pulmonary disease and diabetes. COPD Research and Practice 2015; 1:3.

13. Shishani $K$, Nawafleh $H$, and Sivarajan FE. Jordanian Nurses' and Physicians' Learning Needs for Promoting Smoking Cessation. Progress in Cardiovascular Nursing 2008; 23: 79-83

14. Wafy S, Agamy G, Ali A. Early spirometric changes in asymptomatic smokers; is it a time dependent? European Respiratory Journal 2016; 48: PA4320.

15. Mistry A, Tyagi R, Kagathara J, Vaidya L, Dholakiya U, Shah C. Comparative study of pulmonary function tests in smokers and nonsmokers. GCSMC J Med Sci. 2014;3(1):22-27.

16. Nawafleh HA, Abo Zead SA, Al-Maghaireh DF. Pulmonary function test: The value among smokers and nonsmokers. Health Science Journal 2012; 6(4):703. 
17. Tager I B. The effects of second-hand and direct exposure to tobacco smoke on asthma and lung function in adolescence Paediatric Respiratory Reviews 2008; 9 (1): 29-38.

18. Orton S, Jones LL, Cooper S, Lewis S, and Coleman T. Predictors of children's secondhand smoke exposure at home: A systematic review and narrative synthesis of the evidence PLOS ONE 2014; 9(11): e112690.

19. Karia RM, Gokhale PA, and Mehta HB. Comparative study of spirometric parameters between active tobacco smokers and tobacco nonsmokers. IOSR Journal of Pharmacy. 2012;2(2):222-2

20. Hasan MQ and Sulaiman KH. Comparison of pulmonary function test between smokers and nonsmokers at Hawler medical university, Erbil, Iraq. Medical Journal of Babylon 2019;16(2): 123-127

21. Dugral E and Balkanci D. Effects of smoking and physical exercise on respiratory function test results in students of university A cross-sectional study. Medicine 2019; 98.32 .

22. Bohadana A, Teculescu D and YMartinet $Y$. Mechanisms of chronic airway obstruction in smokers. Respiratory Medicine 2004; 98(2):139151

23. Barthwal MS and Singh S. Early detection of chronic obstructive pulmonary disease in asymptomatic smokers using spirometry. J Assoc Physicians India 2014;62(3):238-42

24. Sophie K, Singh $\mathbf{N}$ and Dharvey AJ. Study of pulmonary function test in asymptomatic smokers and non-smokers between 30-50 years of age in a tertiary care hospital. Int J Adv Med 2017;4: 95963.

25. Isah MD, Makusidi MA, Abbas A, Okpapi JU, Njoku CH, Abba AA. Spirometric evaluation of ventilatory function in adult male cigarette smokers in Sokoto Metropolis. Medical journal 2017; 24(1): 1-7.

26. Khalil MM, Mohammed RM and Hassan OH. A study of the relationship between pulmonary function tests and both fasting plasma glucose and glycated hemoglobin levels among asymptomatic cigarette smokers. Egypt J Bronchol 2019; 13:51622.

27. Chen Y, Li X-q, Li H-r, Miao Y, Lian Sq, Luff et al. Risk factors for small airway obstruction among Chinese island residents: A Case-Control Study. PLoS ONE 2013; 8(7): e68556.

28. Nighute $\mathbf{S}$ and Awari A. Study of pulmonary function test in smoker and non-smoker in rural area of Gujarat. Journal of Clinical and Diagnostic Research 2011; 5:1151-3

29. Urrutia I, Capelastegui A, Quintana JM, Muñiozguren N, Basagana X, Sunyer J, et al. Smoking habit, respiratory symptoms, and lung function in young adults. Eur J Public Health. 2005;15(2):160-65.

30. Cho NH, Chan JC, Jang HC, Lim S, Kim HL Choi SH. Cigarette smoking is an independent risk factor for type 2 diabetes: a four-year community-based prospective study. Clinical endocrinology 2009;71: 679-685.

31. Soulimane S, Simon D, Herman WH, Lange C, Lee CM, Colagiuri S, et al. HbA1c, fasting and $2 \mathrm{~h}$ plasma glucose in current, ex-and never smokers: a meta-analysis. Diabetologia 2014; 57 : 30-39.

32. McCulloch $\mathbf{P}$, Lee $\mathrm{S}$, Higgins $\mathbf{R}$, McCall $\mathrm{K}$, Schade DS. Effect of smoking on hemoglobin A1c and body mass index in patients with type 2 diabetes mellitus. J Investig Med 2002;50(4):2847.

33. Foy CG, Bell RA, Farmer DF, Goff DC Jr and Wagenknecht LE. Smoking and incidence of diabetes among U.S. adults: findings from the insulin resistance atherosclerosis study. Diabetes Care 2005; 28(10):2501-7.

34. Akter S, Okazaki H, Kuwahara K, Miyamoto T, Murakami T, Shimizu C et al. "Smoking, smoking cessation, and the risk of type 2 diabetes among Japanese adults: Japan epidemiology collaboration on occupational health study."PLoS One 2015; 10(7):e0132166.

35. Sang-Mo J, Eun-Ki K, Ho-Hyun L, KyungMoon J, Joo-Wha $\mathbf{P}$, Jun $K$ et al. The relationship between Smoking and Hemoglobin A1c in adults without diabetes mellitus according to body mass index. Korean J Fam Pract 2016; 6 (4):339-345.

36. Jamatia SN, Wangkheimayum K, Singh WA, and Yumnam G. Effect of glycemic status on lung function tests in type 2 diabetes mellitus. J Med Soc 2014; 28(2):69.

37. Tina L, Andriopoulos P, Geogantas P. Diabetes mellitus and airway obstruction: Is there an association? Adv Practice Nurs 2016; 2:116.

38. Litonjua AA, Lazarus R, Sparrow D, Demolles D and Weiss ST. Lung function in type 2 diabetes: The normative aging study. Respir Med 2005; 99:1583-1590.

39. Kwon CH, Rhee EJ, Song JU, Kim JT, Kwag HJ and Sung KC. Reduced lung function is independently associated with increased risk of type 2 diabetes in Korean men. Cardiovasc Diabetol 2012; 11:38.

40. Baba S, Takashima T, Hirota M, Kawashima M, and Horikawa E. Relationship between pulmonary function and elevated Glycated hemoglobin levels in health checkups: A crosssectional observational study in Japanese participants. Journal of Epidemiology 2017; $511 \mathrm{e} 515512$. 


\section{الماخص المربي}

تقييم آثار تلخين السجائر على وظائف الرئهة واستقلاب الجلوكوز فى مدخنين السجائر الحاليين الأين لا

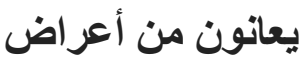

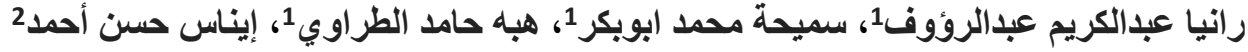

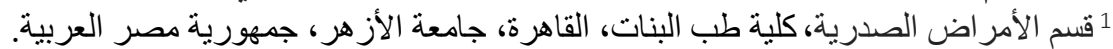

2 قسم الغدد الصماء و الأيض، كلية طب البنات، القاهرة، جامعة الأزهر، جمهورية مصرية الأهر العربية.

ملخص الحث

الخلقية: اعتبر تدخين التبغ عامل خطر لأمر اض لضيق الثعب الهوائية، ومقاومة الأنسولين والإصابة بداء السكري من النوع الثاني. أنز

الهـف: تقييم آثار تدخين السجائر على وظائف الرئة واستقلاب الجلوكوز فى مدخنين السجائر الحاليين الذين

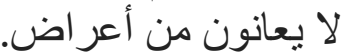

الطرق: أجريت دراسة الحالات والشواهد هذه على 100 من مدخنين السجائر الحاليين الذين لا يعانون من

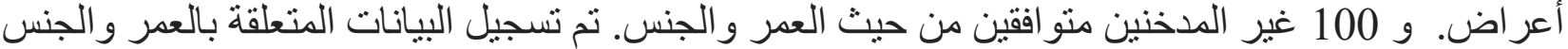
وتاريخ التدخين بما في ذلك سن بدء التدخين ومؤشر التدخين ومدة التدخين. تم قياس مؤشر ات قئن فياس التنفس

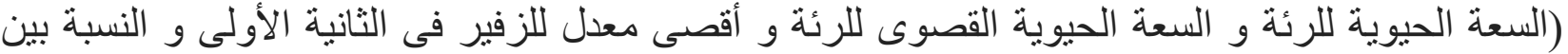

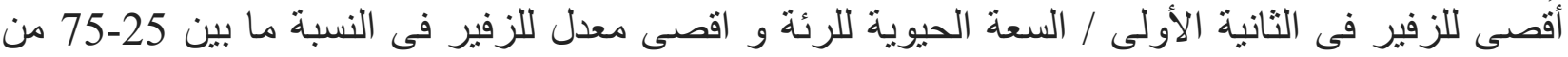

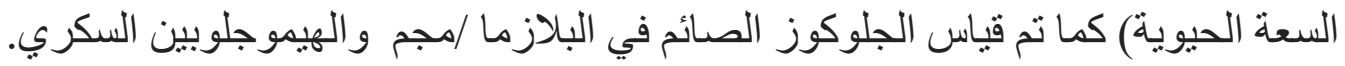

النتائج: كان نمط ضيق الثعب الهوائية و ضيق الثعب الهو اية الصغيرة أعلى إحصائيا في المدخنين الذين لا

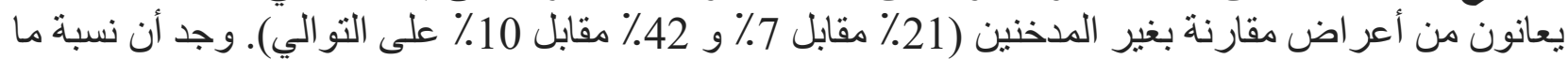

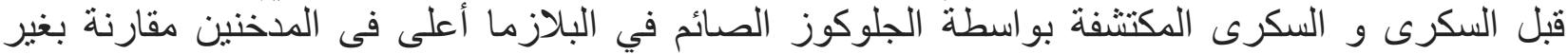

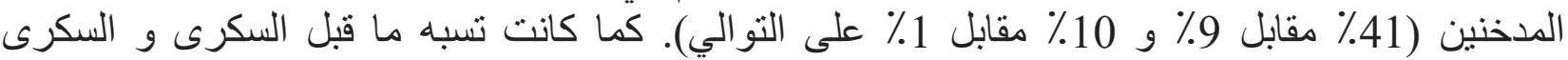

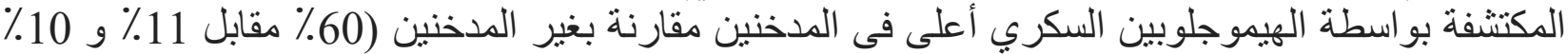

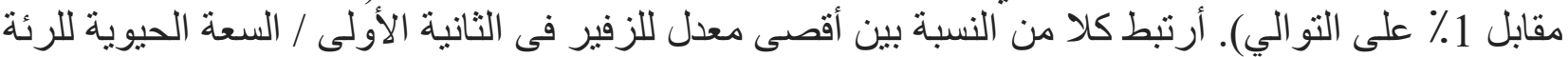

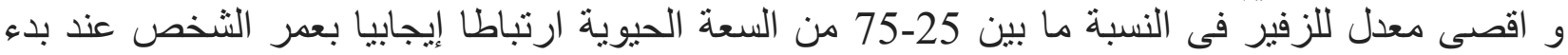

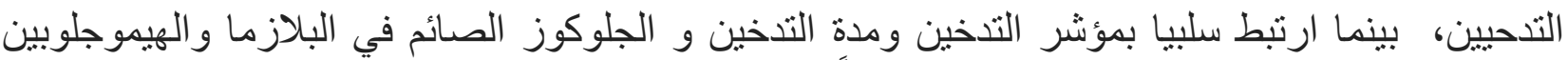

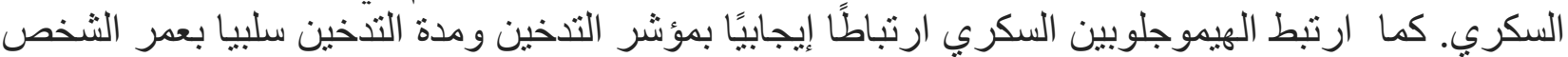
عند بدء التدحيين. وجد أن المدخنون لديهم 17.1 خطر أكبر للإصنابة بالسكرى ، و 3.5 خطر أكبر للإصـابة بضيق الشعب الهو ائية و 6.5 خطر أكبر للإصنابة بضيق الثعب الهوائية الصغيرة مقارنة بغير المدخنين. الاستنتاجات: التدخين عامل خطر للإصـابة بضيق الشعب الهو ائية و ضيق الثعب الهو ائية الصغيرة و مرض السكرى. كلا من وظائف الرئة المنخفضة وزيادة الجلوكوز الصائم في البلازما /مجم و والهيموجلوبة بلين السكري

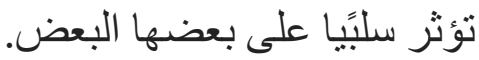

الكلمات المفتاحية: التخخين، اختبار ات وظائف الرئة، الهيمو غلوبين الغليكوزيلاتي، السكري، انسداد مجرى الهو اء الصغير. الأسم: رانيا عبدالكريم عبدالرؤوف، قسم الأمر اض الصدرية، كلية طب البنات، القاهرة، جامعة الأزهر، جمهورية مصر العربية 